\title{
THE NEW BIOLOGICALLY ACTIVE METABOLITES FROM ASPERGILLUS NIVEUS 2411
}

\author{
Ya.I. Savchuk, K.S. Tsyhanenko, \\ O.V. Andrienko, I.M. Kurchenko \\ Zabolotny Institute of Microbiology and Virology, NAS of Ukraine, \\ 154 Acad. Zabolotny Str., Kyiv, 03143, Ukraine \\ e-mail:tsyga@ukr.net
}

\begin{abstract}
Pharmacological science possesses a significant number of compounds with antibiotic activity. By now the chemical structures have been identified and their properties have been described for the great number; many of them found practical use. But the main stimulus for the further new antibiotic compounds search is the acquired resistance of pathogenic organisms. Our previous investigations were devoted to antibiotic activity of Aspergillus niveus that is known as a producer of ferment preparations with wide activity spectrum. Aim. This investigation became the follow-up of our previous studies and its main task was to isolate, purify and obtain biologically active metabolite(s) from A. niveus 2411 strain in crystalline form, and to study its (their) physicochemical properties and biological activity. Methods. Biologically active metabolites were obtained by extraction, two-step column chromatography and recrystallization methods. The obtained substances were characterized by physical-chemical and microbiological methods. Results. Two substances in crystalline form with different spectrum of antibiotic activity against indicator test-cultures were obtained. The substance AN4 showed antibacterial, antifungal, and phytotoxic activities, while AN7 showed only antibacterial activity. Neither of obtained compounds showed dermatocidal or toxigenic activity in rabbit skin test. Obtained spectral characteristics of substances suggest that AN4 and AN7 substances are similar and belong to compounds with cyclic structures, have double linkage, methyl, aromatic, and carboxyl groups. Conclusions. Obtained data showed that antibiotic activity of A. niveus 2411 depend on the complex of biologically active metabolites with different biological and physicochemical properties. Two compounds AN4 and AN7 were isolated and purified from the fungal cultural filtrate of A. niveus 2411. The data of IR and UV spectra of these compounds and their profiles of biological activity don't have significant differences with those of citrinin-a metabolite of A. niveus with antibiotic properties. However, based on the results obtained and comparisons with the data of other authors on metabolites of A. niveus, we suggest that the substances we isolated may be derivatives of citrinin.
\end{abstract}

Keywords: Aspergillus niveus, antibiotic activity, metabolites, citrinin derivatives.

The discovery of penicillin by Alexander Fleming sparked the so called antibiotic era and extensive studies of fungi as a group of the most perspective producers of these biologically active metabolites. By now the chemical structures and properties of the great number of compounds with wide spectrum of action has been described and identified; many of them found practical use in medicine, veterinary, plant growing for struggle with bacterial and fungal pathogens as well as in different fields of industry [1].

At the same time the actively developing resistance of pathogenic microorganisms to preparations employed is the main incentive to search the new antibiotic compounds among different fungal species which were described earlier but weren't investigated from the point of view of synthesis of biologically active metabolites [1-3]. Notably, fungi like that occur even among representatives of Aspergillus and Penicillium genera - real champions among producers [4].

The systemic screening of biological activity of more than 300 potential producers among strains of Aspergillus, Penicillium, Eupenicillium, Paecilomyces, Alternaria, Ulocladium, Bipolaris, Gliocladium, Nectria, Tritirahium, Myrothecium, Beauvenaria, Acremonium, Botriodiplodia, Cephaliophora genera isolated from different ecological niches had been conducted earlier [5-7]. The screening results showed that practically all 
studied fungal strains synthesized biologically active metabolites of different spectrum of action against wide set of test-organisms.

During investigation we paid attention to antibiotic activity of metabolites of Aspergillus niveus Blochwitz (1929) (teleomorph: Fennellia nivea (B.J. Wiley \& E.G. Simmons) Samson (1979)) that is known as a producer of wide spectrum of enzymes $[8,9]$. The group of Brazilian scientists had published the series of articles in which A. niveus was described as producer of amylase [10,11], glucoamylase [10], $\alpha$-glucosidase [12], polygalacturonase [13], $\beta$-fructofuranosidase $[14,15]$, chitinase [16], xylanase [17-19], L-asparaginase [20], pectin lyase [21], $\gamma$-lyase [22], and laccase [23].

Besides enzymes of $A$. niveus are used for obtaining of itaconic acid from agricultural waste [24-26], for purification of distillery effluent [27], for chromium and tannic acid bioremediation [28] and for biosorption of lead ions from aqueous solution [29]. At the same time, only one case of pulmonary aspergillosis caused by A. niveus has been reported in a patient with a weakened immune system [30].

In their fundamental work devoted to new species of section Terrei of Aspergillus by R.A. Samson et al. in 2011 identified following extralites synthesized by $A$. niveus: aszonalenine, butyrolactones, citrinin, and gregatins [9]. Unfortunately, in the available later literature there were no data confirmed the biosyntheses of these biologically active substances by $A$. niveus.

Early we showed the wide spectrum of antibiotic activity for A. niveus 2411 strain [31]. It inhibited the growth of gram-positive testbacteria Staphylococcus aureus, Bacillus subtilis, B. licheniformis, B. megaterium, Micrococcus varians, M. flavus, Mycobacterium smegmatis; gram-negative test-bacteria Escherichia coli and phytopathogens Pseudomonas syringae pv. lachrymans, Pectobacterium carotovorum, as well as test-yeasts (Candida albicans, Kluyveromyces marxianus, Trichosporon cutaneum) and filamentous test-fungi (Phoma betae and A. niger). The aim of this investigation was to isolate, purify and obtain biologically active metabolite(s) from A. niveus 2411 strain in crystalline form, and to study its (their) physicochemical properties and biological activity.

Materials and methods. $A$. niveus 2411 strain was isolated in 2002 from indoor air (Kyiv). This strain is stored in the Ukrainian Collection of
Microorganisms of D.K. Zabolotny Institute of Microbiology and Virology of the NASU. A. niveus 2411 strain was grown (static cultivation) in liquid modified Czapek-Dox medium containing $(\mathrm{g} / \mathrm{L})$ : glucose $-20.0 ; \mathrm{NaNO}_{3}-1.0 ; \mathrm{KH}_{2} \mathrm{PO}_{4}-1.0$; $\mathrm{KCl}-0.5 ; \mathrm{MgSO}_{4} \times 7 \mathrm{H}_{2} \mathrm{O}-0.5 ; \mathrm{FeSO}_{4} \times 7 \mathrm{H}_{2} \mathrm{O}-$ 0.01 in distilled water at $26{ }^{\circ} \mathrm{C}$ for 14 days [32]. Isolation of active metabolites from cultural filtrate was made using the universally accepted scheme. It consisted of following steps: working out the methods of extraction (combined chromatography); extraction itself and accumulation of substrate; primary purification from protein, lipid and pigment impurities; fractionation by column chromatography and recrystallization of active substances [33].

In fitting of extraction conditions, we assumed from the data of combined chromatography performed by Shevchik method [33] and chose chloroform as the best extractant. Extraction was made three times for 15 minutes in 1:4 ratio and obtained extract was vaporized in a rotary vacuum concentrator (Reanal, Hungary) up to 1/10 part of initial volume. Residue was purified from different impurities: precipitation by lead acetate was used for purification from proteins; liquid-liquid redistribution in acetonitrile:hexane system - for purification from lipids; column with activated carbon BAU-1 as an sorbent and methanol as an active phase - for purification from pigments. For removal of moisture residue, obtained substance was passed through sodium sulfate anhydrous [34]. Then partially purified extract was evaporated and fractionized by column chromatography [33].

As a sorbent for column chromatography silica gel L of II grade of activity by Brockman, 100 $160 \mu \mathrm{m}$ particle size (Lachema, Czech Republic) was used. As mobile phase following individual solvents and their systems were used in order of polarity increasing: n-hexane $\rightarrow$ n-hexanechloroform (5:1) $\rightarrow$ chloroform $\rightarrow$ chloroformacetone $(5: 1) \rightarrow$ chloroform-acetone $(9: 1) \rightarrow$ acetone $\rightarrow$ acetone-acetonitrile $(5: 1) \rightarrow$ acetonitrile $\rightarrow$ water. Volume of collected fractions was $50 \mathrm{~mL}$ and flow rate $-0.5 \mathrm{~mL} / \mathrm{min}$. The contents of dry substances were measured by weighing of $5 \mathrm{ml}$ of each fraction after drying at $105^{\circ} \mathrm{C}$ to constant weight.

In obtained fractions the presence of active substances was determined by thin layer chromatography (TLC) and their antibiotic activity against indicator test-cultures Bacillus licheniformis 5 and Kluyveromyces marxianus 899 was estimated by agar disc diffusion assay method (10.0 $\mu \mathrm{L} /$ disk $)$ 
[35]. For TLC $10 \mu \mathrm{L}$ of specimen was applied to Silufol UV254 plates, (Kavallier, Czech Republic); solvent systems of chloroform:methanol (4:1) was used as mobile phase. Visualization of spots on the plates was carried out in iodine saturated developing tank [36] as well as by bioautography method $[37,38]$ using strains $B$. licheniformis 5 and $K$. marxianus as test-cultures.

Active fractions were combined and vaporized in vacuo at $50{ }^{\circ} \mathrm{C}$. Active compounds were recrystallized from benzol. This methodological approach provided the obtaining of homogeneous substance that was visualized on chromatogram as single spot.

Physical-chemical and spectrum characteristics were measured by conventional methods. So, the elemental analysis was detected by Cheronis sodium fusion method [39-41], spectrum characteristics were obtained by spectrophotometers Specord and UR-10 (Germany) in UV-, visible light and IRspectral ranges by spectrophotometers Specord and UR-10 (Germany) in UV-, visible light and IR-spectral ranges [42].

The spectrum of biological activity of obtained preparations was measured by agar well diffusion assay methods (100.0 $\mu \mathrm{L} /$ well) [35]. Strains B. licheniformis 5, B. subtilis 617 , B. subtilis 902, Staphylococcus aureus 904, S. aureus 918, Micrococcus varians 613, M. varians 634, Proteus vulgaris 905, Pectobacterium carotovorum 8636, Agrobacrerium tumefaciens 8464; K. marxianus 899, Candida albicans 690, Trichosporon cutaneum 1502; 6 strains of Chlorella vulgaris and 4 strains of
C. kessleri were used as test-cultures for estimation of antibacterial, antifungal and phytotoxic activities, respectively. Rabbit skin test was used for assess of toxicity of obtained crystallized preparation. The animals, their general state and skin health were under constant observation for 5 days [43].

Results. Data of combined chromatography by Shevchik method when chloroform had been chosen as extractant pointed to moderate polarity of active substance. Initial preparation possessed high antibiotic activity against gram-positive testbacteria and moderate - against gram-negative testbacteria, yeasts and filamentous fungi [31].

Figure 1 demonstrates the results of fractionation of chloroform extract of $A$. niveus 2411. It is shown that substances from fraction 21 are active both against $B$. licheniformis 5 and $K$. marxianus 899 while substances from fraction 27 are active against B. licheniformis 5.

Our assumption about the presence of two compounds with different spectrum of biological action in the preparation were confirmed by TLC of fraction 21 in solvent system chloroform:methanol (4:1) (Fig. 2).

Taking into account the above mentioned we performed the rechromatography of fraction 21 in following solvent system: chloroform $\rightarrow$ chloroform:methanol (97:3) $\rightarrow$ chloroform:methanol (93:7) $\rightarrow$ chloroform:methanol (9:1). It is evident (Fig. 3) that active substance from the fraction on rechromatogram 4 exhibits both antibacterial and antifungal activities whereas active

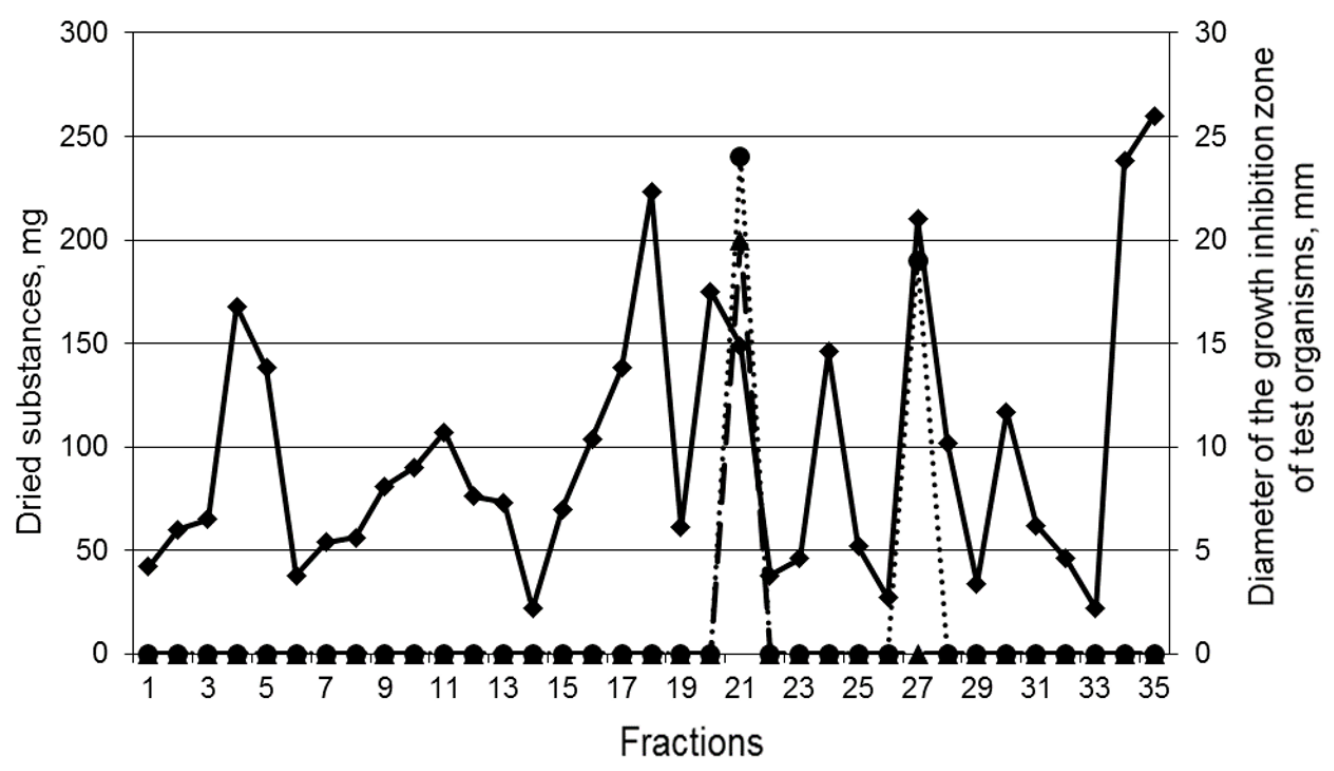

$\longrightarrow$ Dried substances $\cdots \bullet \cdot$ B. licheniformis $5 \rightarrow-$ K. marxianus 899

F i g. 1. Elution profile of preparation from A. niveus 2411 
substance from this fraction on rechromatogram 7 displays activity only against $B$. licheniformis 5 similar to fraction 27 from Fig. 1.

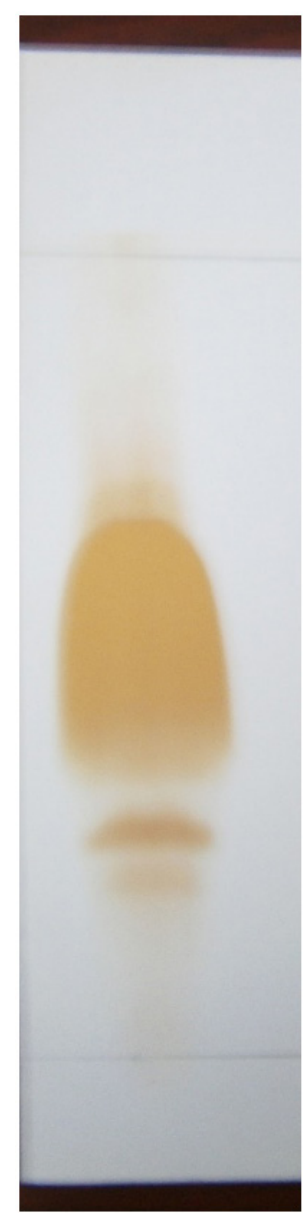

F i g. 2. TLC of preparation from fraction 21
Presented on Fig. 4 TLC of obtained preparations from fractions 4 and 7 in two solvent systems (hexane:benzol:methanol (10:10:3) and ether:toluene:acetone $(2: 2: 1))$ confirmed the presence of two substances with different chromatographic mobility and spectrum of biological activity in initial fraction 21 .

Preparation from fraction 4 in two used solvent systems was presented by single spot with Rf 0.51 and 0.81 , respectively, and showed both antifungal activity against $K$. marxianus 899 and antibacterial activity against $B$. licheniformis 5 . However, the preparation from fraction 7 under same conditions was presented by single spot with Rf 0.38 and 0.48 , respectively, and displayed antibacterial activity only against $B$. licheniformis 5 . Bioautographic confirmation of biological activity of obtained preparation is shown on Fig. 5.

For additional purification the active substances were recrystallized from benzol and labelled as AN4 and AN7, respectively. Spectra of their biological activity are presented on Fig. 6. It was also shown that substance AN4 from fraction 4 displayed high phytotoxic activity against green alga of Chlorella genus (Fig. 7). Obtained preparations AN4 and AN7 did not show any reaction in rabbit skin test.

Elemental analyses of these substances showed the absence of nitrogen, sulphur and halogen atoms in their structure and the presence of main elements of organic substances, namely carbon, hydrogen and oxygen.

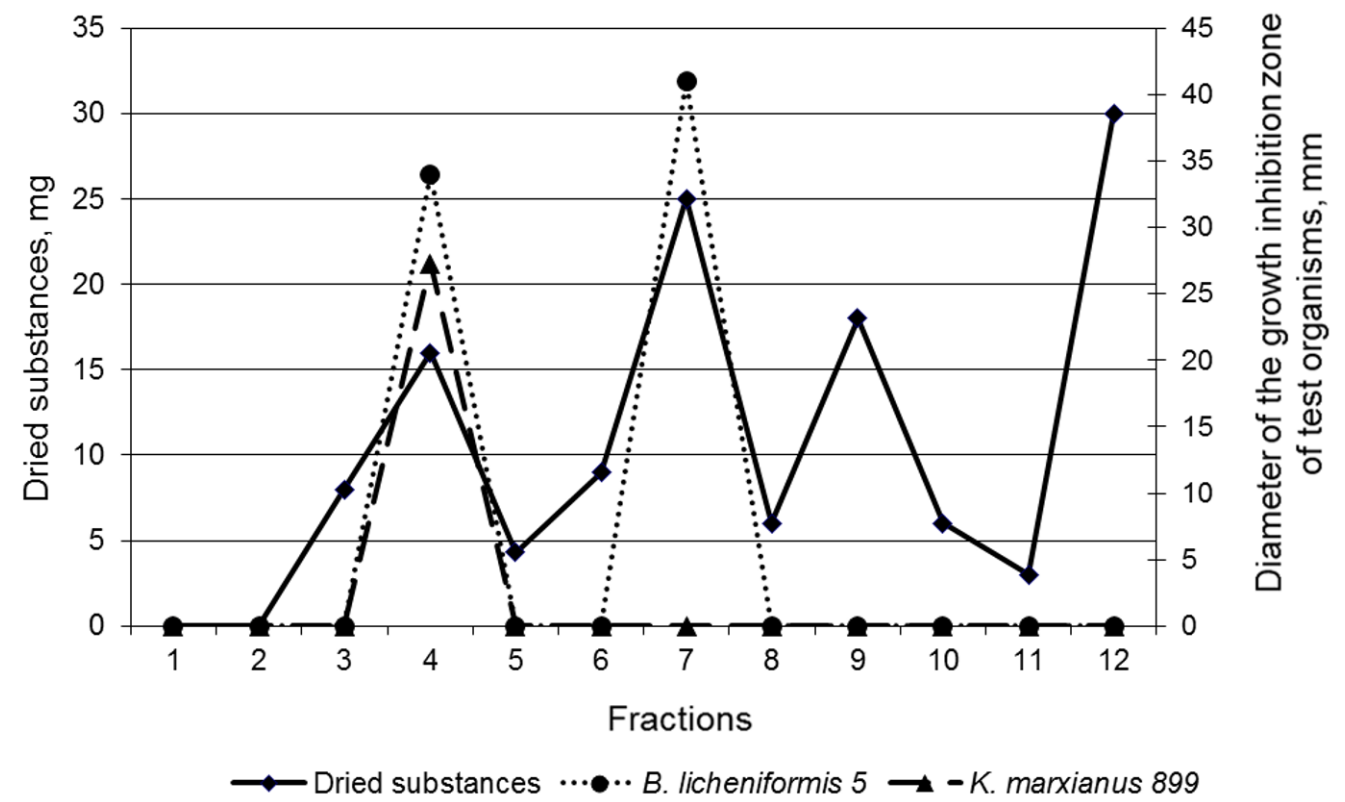

F i g. 3. Elution profile of preparation from fraction 21 
A

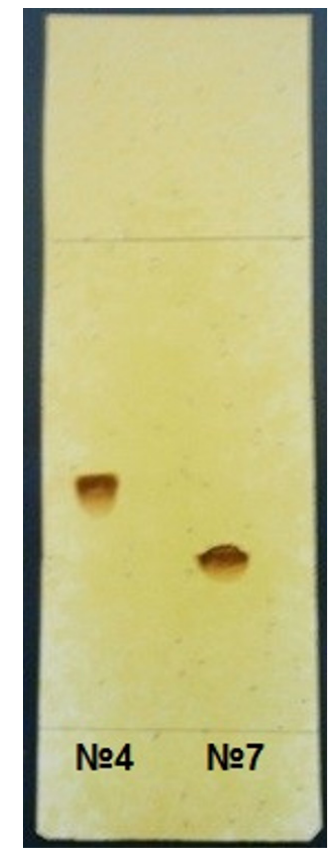

B

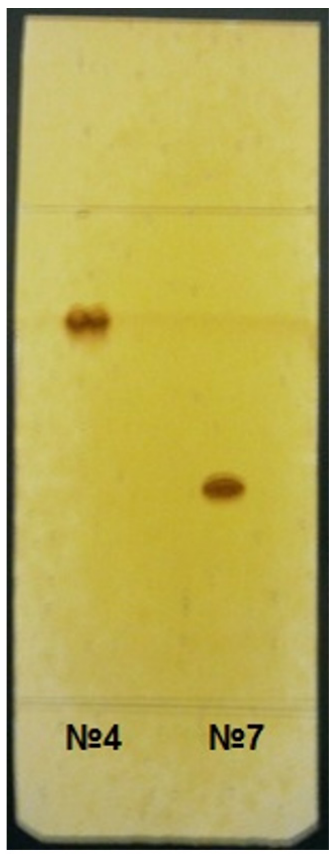

F i g. 4. TLC of preparations from fractions 4 and 7 in solvent systems: a) hexane:benzol:methanol (10:10:3); b) ether:toluene:acetone (2:2:1)

A

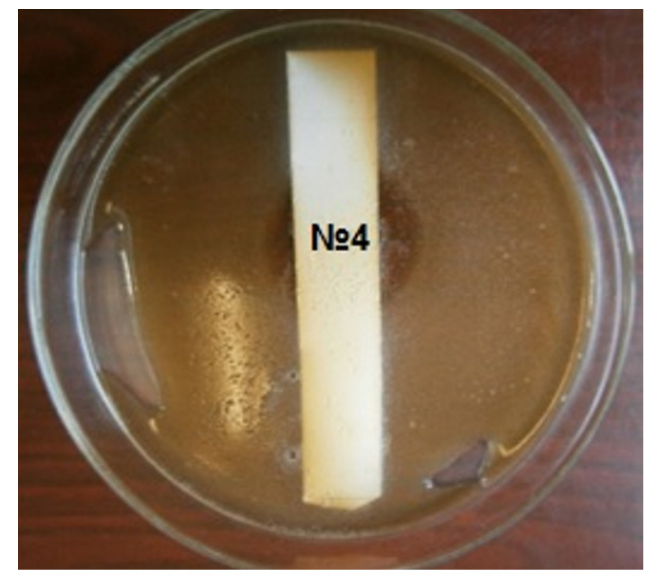

B

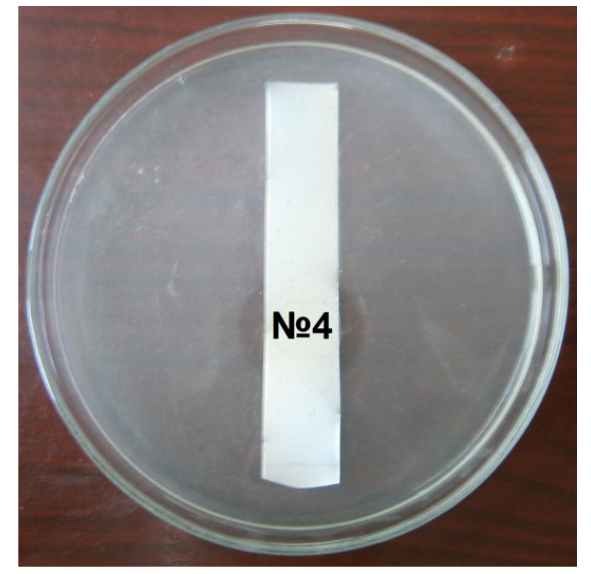

C

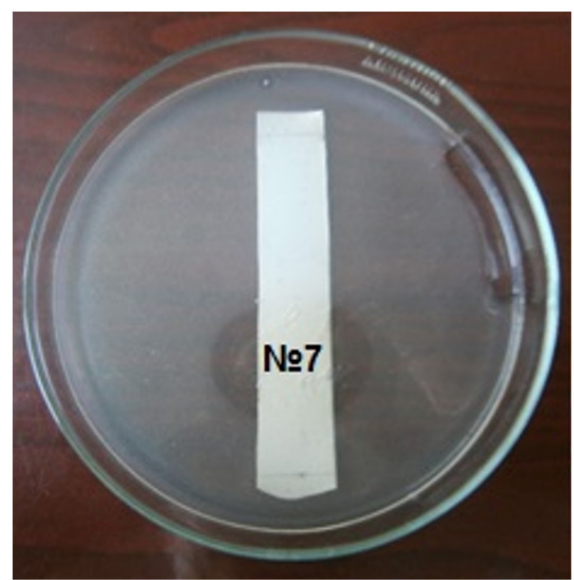

F i g. 5. TLC-bioautography of preparations from fractions 4 and 7 against test-cultures: a) K. marxianus 899; b) and c) B. licheniformis 5 


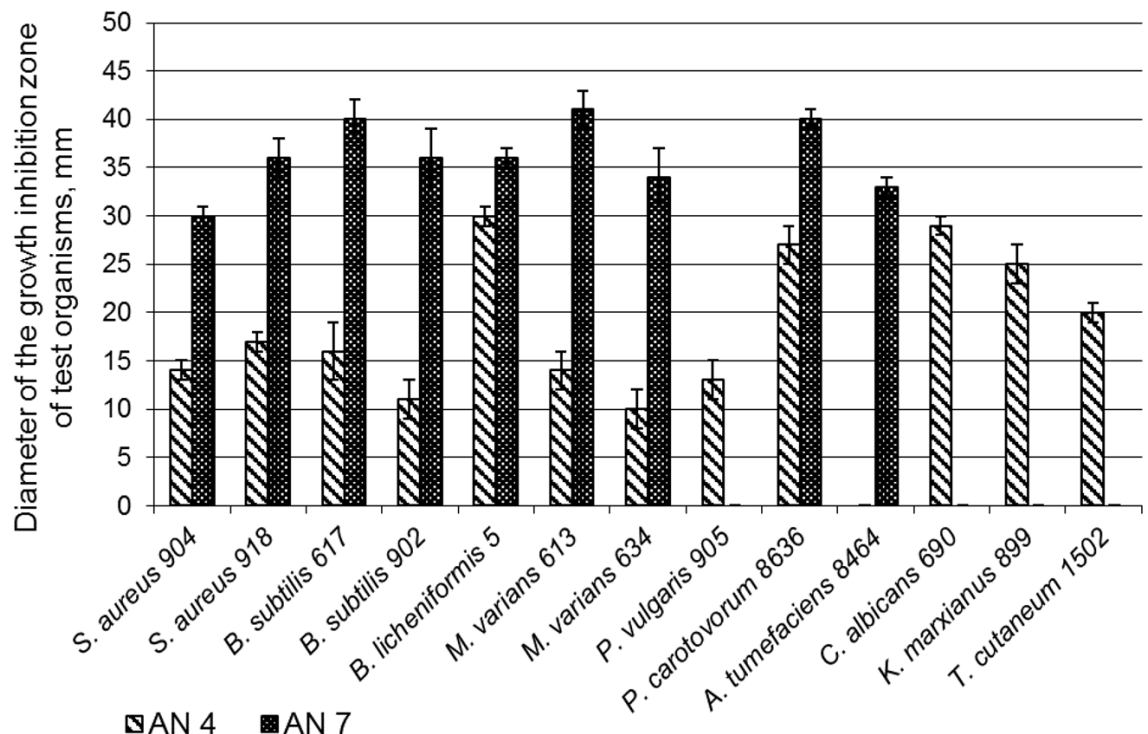

F i g. 6. Biological activity of substances AN4 and AN7

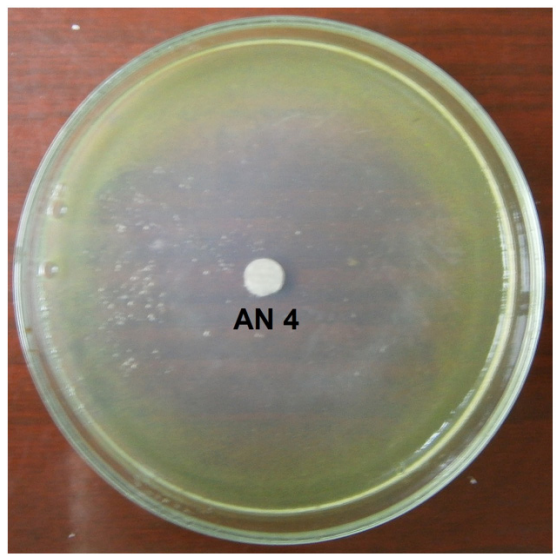

\section{F i g. 7. Phytotoxic activity of substance AN4 against Chlorella vulgaris 189}

The spectrum analyses (Fig. 8) of studied substances revealed the similarity of their structure. In particular, they have two same absorption maxima in UV-rang at wavelengths 215 and 231 $\mathrm{nm}$ but some differences in longwave rang of UVspectrum where the substance AN4 has absorption maximum at $255 \mathrm{~nm}$ and substance AN7 - at 265 nm.

The comparison of obtained data with table levels of absorption maxima of the main classes of organic substances in 200-800 nm diapason allowed to suggest the presence of unsaturated carboxylic acid, cyclic diene as well as derivative of benzol in the structure of substance AN7 [44]. In visible light spectral range any absorption maxima were not marked that is also evidenced by the absence of coloration of the sample.
The IR-spectra of studied substances (Fig. 8) were also alike. The absorption maxima pointed on the presence of double bonds, derivatives of carboxylic acids, aromatic compounds including methylbenzene, acetals, esters, stereoisomers of alkanes and alkenes. As following from the obtained data, the spectrum characteristics of AN4 and AN7 confirm their aromatic character, cyclic structure, the presence of double bonds and methyl, aromatic and carboxylic groups and the necessity of additional chemical identification.

Discussion. This step of investigations was devoted to isolation and purification of biologically active metabolites of $A$. niveus 2411 that displayed antibacterial, antifungal and phytotoxic activities in previous studies [31]. As a result, two substances in crystalline form (arbitrarily called AN4 and AN7) with different spectrum of biological activity against indicator test-cultures were obtained.

Studied physical-chemical characteristics of obtained preparation allow suggesting the presence of certain chemical groups in the structures of AN4 and AN7 but not allowing to judge on this stage of investigation about their entire structures. At the same time, our data are compared with isolated earlier and described in literature biologically active metabolites of Aspergillus section Terrei [9]. It is apparent that obtained by us substances possess structural similarity with citrinin $\left(\mathrm{C}_{13} \mathrm{H}_{14} \mathrm{O}_{5}\right.$, IUPAC: (3R,4S)-4,6-dihydro-8-hydroxy-3,4,5trimethyl-6-oxo-3H-2-benzopyran-7-carboxylic acid) or with its derivatives. The structural formula of this mycotoxin is presented on Figure 9. It is 
A

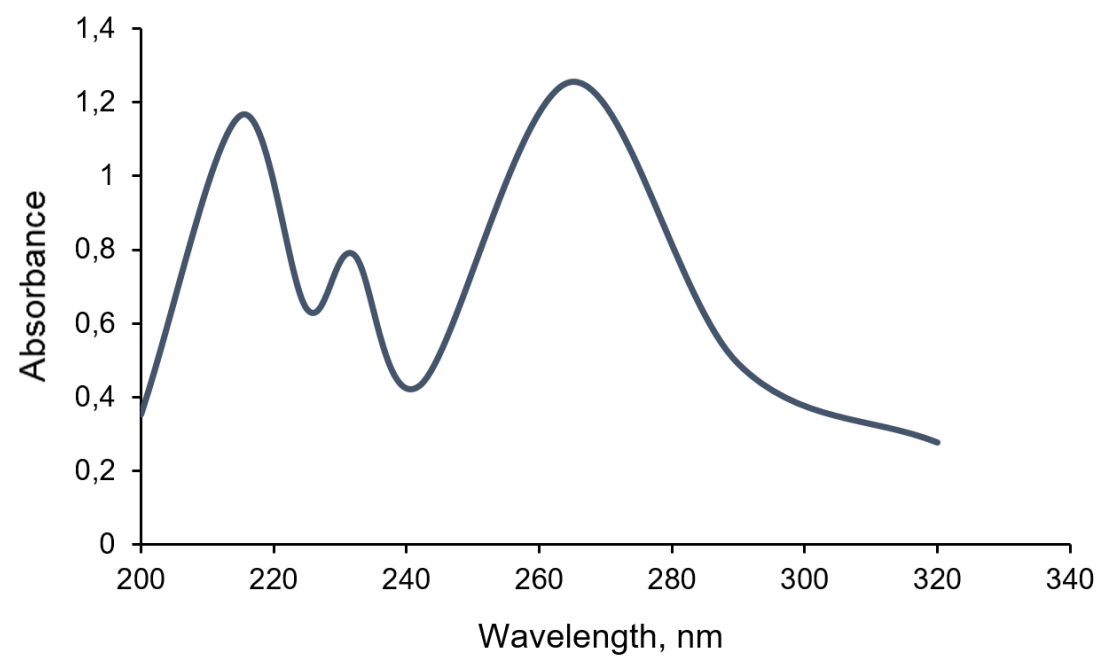

B

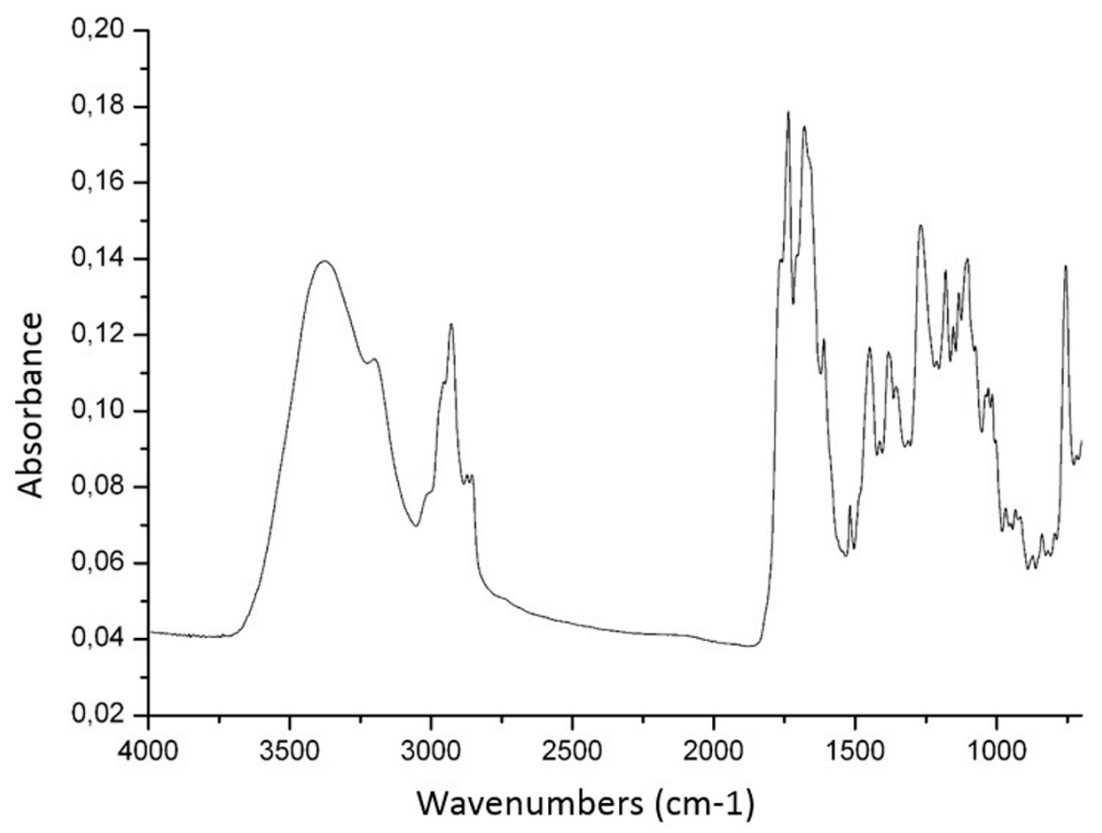

C

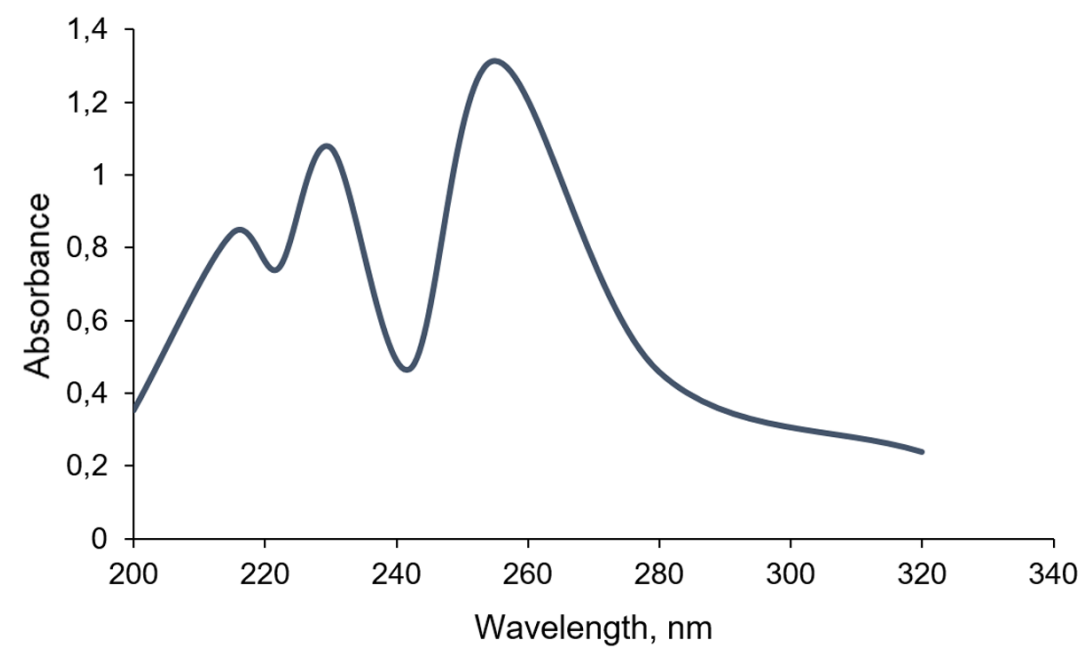

F i g. 8. Absorption spectrum of AN4 preparation: a) UV-absorption, b) IR-absorption; and absorption spectrum of AN7 preparation: c) UV-absorption; d) IR-absorption 


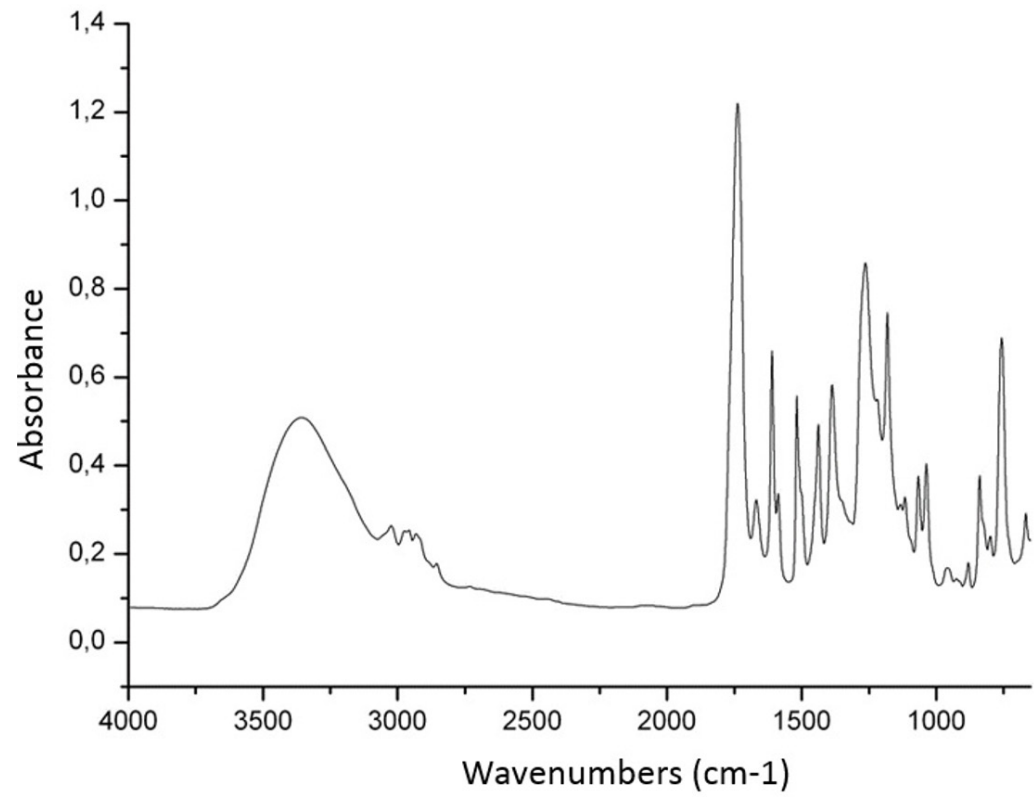

F i g. 8. Panel d

remarkably that R.A. Samson et al. pointed in 2011 on the fact of biosynthesis of this particular mycotoxin, which, in contrast to the other three metabolites of $A$. niveus mentioned by the authors, had broad-spectrum antibiotic activity [9].

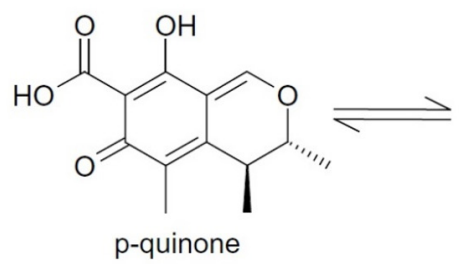<smiles>CC1=C(O)C(C(=O)O)C(=O)C2=CO[C@H](C)C(C)C21</smiles>

\section{F i g. 9. Structural formula of citrinin isomers} [45]

As for biological properties of citrinin it is known that this substance displays antibiotic, antifungal, antiprotozoal properties, and possesses potential anticancer effect [45]. Besides that, this mycotoxin is also known as a hepato-nephrotoxin in a wide range of species [46]. There are some data that spectral characteristics of citrinin derivatives slightly differ by absorption maxima in UV- and IRrange of spectrum and as a consequence can have an influence on physical-chemical and biological properties of these substances that is manifested by different sensitivity of test-microorganisms to them [47], and also affects the level of their toxic action. Antibiotic and antifungal properties of substances obtained by us are analogous to those of citrinin derivatives but in our case none of the two compounds cause even hyperaemia in rabbit skin test and therefore display any dermatocidal action and toxigenic properties that are characteristic for citrinin derivatives described by other researchers $[47,48]$. This fact suggests that isolated by us compounds AN4 and AN7 are new and undescribed earlier biologically active metabolites of $A$. niveus with antagonistic activity.

Conclusions. Obtained data showed that antibiotic activity of Aspergillus niveus 2411 depend on the complex of biologically active metabolites with different biological and physicochemical properties. Two compounds AN4 and AN7 were isolated and purified from the fungal cultural filtrate of $A$. niveus 2411. The data of IR and UV spectra of these compounds and their profiles of biological activity don't have significant differences from those of citrinin - a metabolite of A. niveus with antibiotic properties. However, based on the results obtained and comparisons with the data of other authors on metabolites of $A$. niveus, we suggest that the substances we isolated may be derivatives of citrinin. The necessity of further investigations of A. niveus 2411 metabolites is obvious. These studies will answer the questions about the nature of these structures for their final chemical identification as well as their action mechanism on cells of different test-organisms including cancer cells.

Acknowledgments. The authors are thankful to Prof. Nelli M. Zhdanova for donation of Aspergillus niveus strain 2411 from Culture collection of 
Department of Physiology and Taxonomy of Micromycetes of D.K. Zabolotny Institute of Microbiology and Virology of NAS of Ukraine and to Prof. Alexander M. Zaichenko for fruitful discussions.

\section{НОВІ БІОЛОГІЧНО АКТИВНІ МЕТАБОЛІТИ ASPERGILLUS NIVEUS 2411}

\section{Я.І. Савчук, К.С. Циганенко, О.В. Андріснко, І.М. Курченко}

Інститут мікробіології і вірусології ім. Д.К. Заболотного НАН Украӥни, вул. Академіка Заболотного, 154, Київ, 03143, Украӥна

\section{Резюме}

Фармакологічна наука зараз має у своєму розпорядженні значну кількість сполук, що проявляють антибіотичну активність. У багатьох з них досліджено властивості та ідентифіковано хімічні структури, деякі 3 них знайшли практичне застосування. Але основним рушієм для подальшого пошуку нових антибіотичних сполук $є$ набута резистентність патогенних організмів. В попередніх дослідженнях нашу увагу привернула антибактеріальна активність гриба Aspergillus niveus відомого продуцента широкого спектра ферментів. Таким чином, представлене дослідження $\epsilon$ продовженням циклу робіт, присвячених пошуку нових біологічно активних речовин. Мета. Ізолювання, очистка, отримання в кристалічному вигляді біологічно активних метаболітів (у) гриба A. niveus 2411 та дослідження його (іхнніх) фізикохімічних властивостей і біологічної активності. Методи. Штам A. niveus 2411 вирощували у рідкому середовищі Чапека-Докса за температури $26^{\circ} \mathrm{C}$ впродовж 14 діб. Виділення активних метаболітів з культурального фільтрату проводили за універсальною схемою, яка включала екстракцію; первинне очищення від білкових, ліпідних і пігментних домішок; фракціонування за допомогою колонкової хроматографії і перекристалізацію отриманих активних речовин. Отримані речовини пропускали через сульфат натрію безводний; частково очищений екстракт випаровували і фракціонували за допомогою двоступеневої колонкової хроматографії. Як сорбент для колонкової хроматографії використовували силікагель L II ст. активності за Брокманом, розмір частинок
100-160 мкм (Lachema, Чехія). Як рухому фазу використовували окремі розчинники та їх системи в порядку зростання полярності. Наявність активних речовин в отриманих фракціях визначали методом тонкошарової хроматографії та оцінювали їхню антибіотичну активність щодо індикаторних тесткультур методом дифузії в агар. Активні фракції об'єднували і випаровували під вакуумом $3950^{\circ} \mathrm{C}$; активні сполуки перекристалізовували. Фізикохімічні і спектральні характеристики визначали загальноприйнятими методами; спектр біологічної активності отриманих препаратів визначали методом лунок в агарі. Результати. У кристалічному вигляді отримано дві сполуки, які проявляли антибіотичну активність різного спектру дії щодо індикаторних тест-культур: AN4, що проявляла антибактеріальну (Bacillus licheniformis 5, B. subtilis 617 i 902, Staphylococcus aureus 918, Micrococcus varians 613 i 634, Proteus vulgaris 905, Pectobacterium carotovorum 8636), антифунгальну (Kluyveromyces marxianus 899, Candida albicans 690, Trichosporon cutaneum 1502) і фітотоксичну (10 штамів видів роду Chlorella) активності; та AN7, що проявляла лише антибактеріальну (B. licheniformis 5, B. subtilis 617 i 902, S. aureus 918, M. varians 613 i 634, P. carotovorum 8636, A. tumefaciens 8464) активність. Жодна з отриманих сполук не мала дерматоцидної дії у шкірній пробі на кролику і не проявляла токсичних властивостей. Спектральні характеристики виявили подібність виділених AN4 i AN7 та вказали на ароматичний характер цих сполук, що мають циклічну структуру, подвійні зв 'язки, метильні, ароматичну і карбоксильну групи. Висновки. Отримані дані показали, що антибіотичні властивості дослідженого гриба $A$. niveus 2411 обумовлені низкою біологічно активних метаболітів, що відрізняються за біологічними і фізико-хімічними властивостями. 3 культурального фільтрату гриба виділено та очищено дві сполуки AN4 і AN7. Дані ІЧ- та УФспектрів цих сполук, а також їхні профілі біологічної активності відрізняються незначною мірою від таких цитриніну - метаболіту A. niveus 3 антибіотичними властивостями. Проте, з огляду на отримані результати і порівняння з даними інших авторів щодо метаболітів A. niveus ми припускаємо, що виділені нами речовини можуть бути похідними цитриніну.

Ключові слова: Aspergillus niveus, антибіотична активність, метаболіти, похідні цитриніну. 
1. Martens E, Demain AL. The antibiotic resistance crisis, with a focus on the United States. J Antibiot. 2017; 70:520-6.

2. Arias CA, Murray BE. A New antibiotic and the evolution of resistance. N Engl J Med. 2015; 372(12):1168-70.

3. Hughes D, Andersson DI. Evolutionary trajectories to antibiotic resistance. Ann Rev Microbiol. 2017; 71:579-96.

4. Bilai VI, Kurbatskaia ZA. [Identifier for toxin-forming micromycetes]. Kyiv: Nauk. dumka; 1990. Russian.

5. Tsyganenko KS, Zaichenko OM. [Antibiotic properties of some species of genus Aspergillus Mich.]. Mikrobiol Z. 2004; 66(4):56-61. Ukrainian

6. Savchuk YaI, Zaichenko OM. [Evaluation of potential of micromycetes concerning synthesis of biologically active substances]. Mikrobiol Z. 2010; 72(2):15-21. Ukrainian.

7. Tsyganenko KS, Savchuk YaI, Nakonechna LT, Kurchenko IM. The biological activity of Alternaria species. Mikrobiol Z. 2018; 80(4):78-87.

8. Blochwitz A. Die Gattung Aspergillus. neue Spezies. Diagnosen. Synonyme. Annales Mycologici. 1929; 27(3-4):205-40.

9. Samson RA, Peterson SW, Frisvad JC, Varga J. New species in Aspergillus section Terrei. Stud Mycol. 2011; 69:39-55.

10. Silva TM, Alarcon RF, Damasio ARL, Michelin M, Maller A, Masui DC, Terenzi HF, Jorge JA, Polizeli MLTM. Use of cassava peel as carbon source for production of amylolytic enzymes by Aspergillus niveus. Int J Food Eng. 2009; 5(5):1.

11. Silva TM, Maller A, Peixoto-Nogueira SC, Michelin M, Jorge JA, Polizeli MLTM. Evidence of high production levels of thermostable dextrinizing and saccharogenic amylases by Aspergillus niveus. Afr J Biotechnol. 2013; 12(15):1874-81.

12. Silva TM, Michelin M, Damasio ARL, Maller A, Almeida FBDR, Ruller R, Ward RJ, Rosa JC, Jorge JA, Terenzi HF, Polizeli MLTM. Purification and biochemical characterization of a novel $\alpha$-glucosidase from Aspergillus niveus. Antonie van Leeuwenhoek. 2009; 96:569-78.

13. Maller A, Damasio ARL, Silva TM, Jorge JA, Terenzi HF, Polizeli MLTM. Biotechnological potential of agro-industrial wastes as a carbon source to thermostable polygalacturonase production in Aspergillus niveus. Enzyme Res. 2011; e289206.

14. Guimaraes LHS, Somera AF, Terenzi HF, Polizeli MLTM, Jorge JA. Production of $\beta$-fructofuranosidases by Aspergillus niveus using agroindustrial residues as carbon sources: Characterization of an intracellular enzyme accumulated in the presence of glucose. Process Biochem. 2009; 44:237-41.

15. Fernandes MLP, Jorge JA, Guimaraes LHS. Characterization of an extracellular $\beta$-D-fructofuranosidase produced by Aspergillus niveus during solid-state fermentation (SSF) of cassava husk. J Food Biochem. 2017; e12443.

16. Alves TB, Ornela PHO, Oliveira ACO, Jorge JA, Guimaraes LHS. Production and characterization of a thermostable antifungal chitinase secreted by the filamentous fungus Aspergillus niveus under submerged fermentation. 3 Biotech. 2018; 8:369.

17. Betini JHA, Michelin M, Peixoto-Nogueira SC, Jorge JA, Terenzi HF, Polizeli MLTM. Xylanases from Aspergillus niger, Aspergillus niveus and Aspergillus ochraceus produced under solid-state fermentation and their application in cellulose pulp bleaching. Bioprocess Biosyst Eng. 2009; 32:819-24.

18. Damasio ARL, Silva TM, Almeida FBR, Squina FM, Ribeiro DA, Leme AFP, Segato F, Prade RA, Jorge JA, Terenzi HF, Polizeli MLTM. Heterologous expression of an Aspergillus niveus xylanase GH11 in Aspergillus nidulans and its characterization and application. Process Biochem. 2011; 46:1236-42.

19. Sudan R, Bajaj BK. Production and biochemical characterization of xylanase from an alkalitolerant novel species Aspergillus niveus RS2. World J Microbiol Biotechnol. 2007; 23:491-500.

20. Amatto IVS, Guimaraes LHS. Production of L-asparaginase by Aspergillus niveus under solid-state fermentation using agroindustrial byproducts. Int J Sci Rep. 2019; 5(9):232-39.

21. Maller A, Silva TM, Damásio ARL, Reis VRA, Jorge JA, Polizeli MLTM. Production of Pectin Lyase by Aspergillus niveus under Submerged 
and Solid State Fermentations Using Agro-Industrial Residues as Carbon Sources. Int Res J Microbiol. 2012; 3(1):29-35.

22. El-Sayed AS, Khalaf SA, Abdel-Hamid G, El-Batrik MI. Screening, morphological and molecular characterization of fungi producing cystathionine $\gamma$-Lyase. Acta Biol Hung. 2015; 66(1):119-32.

23. Peixoto-Nogueira SC, Betini JHA, Michelin M, Carvalho CC, Lucca AL, Vici AC, Jorge JA, Polizeli MLTM. Laccase production by Aspergillus niveus on SSF using wheat bran as alternative carbon source and its synergistic effect on pulp biobleaching using a mix of laccase/xylanase from the same microorganism. J Biochem Tech. 2015; 6(2):929-37.

24. Gnanasekaran R, Dhandapani B, Gopinath KP, Iyyappan J. Synthesis of itaconic acid from agricultural waste using novel Aspergillus niveus. Prep Biochem Biotechnol. 2018; 48(7):605-9.

25. Gnanasekaran R, Dhandapani B, Iyyappan J. Improved itaconic acid production by Aspergillus niveus using blended algal biomass hydrolysate and glycerol as substrates. Bioresource Technol. 2019; 283:297-302.

26. Gnanasekaran R, Saranya P, Yuvashree S, Yuvaraj D, Saravanan A, Smila KH, Anli Dino A. Itaconic acid production by novel Aspergillus niveus in solid state fermentation using agrowastes. Int J Eng Technol. 2018; 7:76-81.

27. Angayarkanni J, Palaniswamy M, Swaminathan K. Biotreatment of distillery effluent using Aspergillus niveus. Bull Environ Contam Toxicol. 2003; 70:268-77.

28. Chaudhary P, Chhokar V, Choudhary P, Kumar A, Beniwal V. Optimization of chromium and tannic acid bioremediation by Aspergillus niveus using Plackett-Burman design and response surface methodology. AMB Expr. 2017; 7:201.

29. Karaca H, Tay T, Kivan M. Kinetics of lead ion biosorption from aqueous solution onto lyophilized Aspergillus niveus. Water Pract Technol. 2010; 5(1):wpt2010020.

30. Auberger J, Lass-Flörl C, Clausen J, Bellmann R, Buzina W, Gastl G, Nachbaur D. First case of breakthrough pulmonary Aspergillus niveus infection in a patient after allogeneic hematopoietic stem cell transplantation. Diagn Microbiol
Infect Dis. 2008; 62:336-39.

31. Savchuk YaI, Tsyganenko KS, Zaichenko OM. [Antibiotic activity of some fungi]. Mikrobiol Z. 2013; 75(5):52-61. Ukrainian.

32. Khalid MM, Sudhir Ch. A modified medium for antibiotic production by Aspergillus spp. antagonistic to citrus cancer pathogen. Nat Acad Sci Lett. 1989; 12(4):103-6.

33. Bilai VI, editor. [Methods of experimental mycology]. Kyiv: Naukova dumka; 1982. Russian.

34. Zaichenko AM, Sobolev VS, Kirillova LM, Rubezhniak IG. [Toxigenic potential of Dendrodochium and Myrothecium Species]. Mikrobiol Z. 1994; 56(1):59-60. Russian.

35. Balouiri M, Sadiki M, Ibnsouda SK. Methods for in vitro evaluating antimicrobial activity: A review. J Pharm Anal. 2016; 6(2):71-9.

36. Lurie AA. [Materials for chromatography]. Moscow: Chemistry; 1978. Russian.

37. Marston A. Thin-layer chromatography with biological detection in phytochemistry. J Chromatogr A. 2011; 1218(19):2676-83.

38. Dewanjee S, Gangopadhyay M, Bhattabharya N, Khanra R, Dua TK. Bioautography and its scope in the field of natural product chemistry. J Pharm Anal. 2015; 5(2):75-84.

39. Cheronis ND. [Micro and semimicro methods of organic chemistry]. Terentiev AP, editor. Moscow: Foreign Literature Publishing House; 1960. Russian.

40. Voskresenskiy PI. [Laboratory technique]. Moscow-Leningrad: Chemistry; 1964. Russian.

41. Alimarin IP, Busev AI, Vinogradov AP, Ermakov AN, et al. [Analytical chemistry of phosphorus]. Moscow: Science, 1974. Russian.

42. Majewski WA, Pfanstiel JF, Plusquellic DF, Pratt DW. High resolution optical spectroscopy in the UV. Laser techniques in chemistry. 1995; 23:101-48.

43. Mannapova RT. Microbiology and mycology. Especially dangerous infectious diseases, mycoses, and mycotoxicosis. Moscow: Prospect; 2018.

44. Lazurevskiy GV, Terentieva IV, Shamshurin AA. [Practicum on the natural compounds chemistry]. Moscow: Higher School; 1966. Russian.

45. Filho JWGO, Islam MT, Ali ES, Uddin SJ, Santos JVO, Alencar MVOB, Gomes Júnior AL, 
Paz MFCJ, Brito MDRM, Sousa JMCE, Shaw S, Medeiros MGF, Dantas SMMM, Rolim HML, Ferreira PMP, Kamal MA, Pieczynska MD, Das N, Gupta VK, Mocan A, Andrade TJADO, Singh BN, Mishra SK, Atanasov AG, Melo-Cavalcante AAC. A comprehensive review on biological properties of citrinin. Food Chem Toxicol. 2017; 110:130-41.

46. Xu BJ, Jia XQ, Gu LJ, Sung CK. Review on the qualitative and quantitative analysis of the mycotoxin citrinin. Food Control. 2006; 17:271-85.
47. Wang ML, Lu CH, Xu QY, Song SY, Hu ZY, Zheng ZH. Four New Citrinin derivatives from a marine-derived Penicillium sp. fungal strain. Molecules. 2013; 18:5723-35.

48. Subramani R, Kumar R, Prasad P, Aalbersberg W. Cytotoxic and antibacterial substances against multi-drug resistant pathogens from marine sponge symbiont: Citrinin, a secondary metabolite of Penicillium sp. Asian Pac J Trop Biomed 2013; 3(4):291-96.

Received 2.01.2021 